\title{
Artefacts on Display: Museum Narrative for the Bulgarian National Revival Period
}

The term "National Revival period" in Bulgarian history refers mainly to the $19^{\text {th }}$ century. The nomination stands for the historical processes, which lead to achieving liberty from the Ottoman Empire. These include the activities in relation to establishing a secular modern Bulgarian education, the struggle for independent Bulgarian church (1870) and were finalized with achieving the Liberation of Bulgaria in 1878 as result of the Russian-Ottoman war of 1877-1878. The April Uprising of 1876 - a revolutionary revolt, organized entirely by the Bulgarians both in the country and abroad, is considered the peak of the period, and despite its unsuccessful outcome acted as the sparkle, which unlocked foreign actions, triggered by the atrocities of the Ottoman authorities. By the means of its nature, the National Revival is the time of the consolidation of the Bulgarian nation in the $19^{\text {th }}$ century in parallel to all other European nations.

Bulgarian museums, which present the National Revival period, form a whole category of exhibitions, the specifics of which are recognizable to a wide range of audiences. The messages in these museums are not entirely unknown; on the contrary - there are certain preliminary expectations for them, the answer to which leads to satisfaction from the visit. In the minds of many Bulgarians, visiting these exhibitions, as well as the satisfaction of this act, are „mandatory”. 
By definition, the object (cultural value) is a fundamental segment in the construction of an exhibition, as artefacts and collections are the basis for the creation of the museum institution. Specialists see in the expositional representation the promotion of the idea of progress (progress) both through the emphasis on technological development and through the charisma of the original item [Walsh 2002: 36]. In addition, the relics of the National Revival have an even stronger national-consolidating function, as together with the artefacts from the glorious Middle Ages, they are the first objects collected immediately after the Liberation during the formation of the National Museum and the first museums in the country.

Jean Baudrillard sees the ancient object as the equivalent of a myth of origin. It is a completed object in the past perfect tense (equivalent to a completed act), has a special status, and its non-functionality distances it from the modern world and makes it attractive [Baudrillard 2003: 79].

In the most general sense, the museums for the Bulgarian Revival display three categories of objects - „relics of the era” (originals related to the person or event), „representative objects” (most often again originals, but not belonging to the declared context) and „replicas” (copies of existing or nonexistent relics). The most common example of the use of representational objects is the use of ethnographic materials to recreate the situation „In the home of the hero."

\section{Relics - representations - replicas}

The presence of relics (original items of the hero) is elevated on a pedestal in museums that narrate for the National Revival. The permanent exhibitions are a place for everyday expression of the official national narrative by materializing events and personalities, and the artefacts in them are accepted as evidence, verifying the truth of the presented stories [Nenov 2018: 7]. The „necessity” of having such testimonies — objects, related not just to time, but to individuals themselves - leads to special situations. For example, as of 2020, four rifles in museums across the country are attributed to the revolutionary Panayot Volov; two sabres and two flintlock pistols are attributed as a personal weapon to the revolutionary Georgi Rakovski [Roshkeva 2018: 115].

The special attitude towards the relics is a fact that is physically visible in the construction of the museum narrative. At the Hristo Botev National Museum in Kalofer, in a window case at the end of the exhibition path, are 
presented a pocket watch with a winding key, an ink absorber, a blue glass inkwell and a horseshoe-shaped pen holder. The annotation in front of the objects reads "The only preserved personal belongings of Hristo Botev".

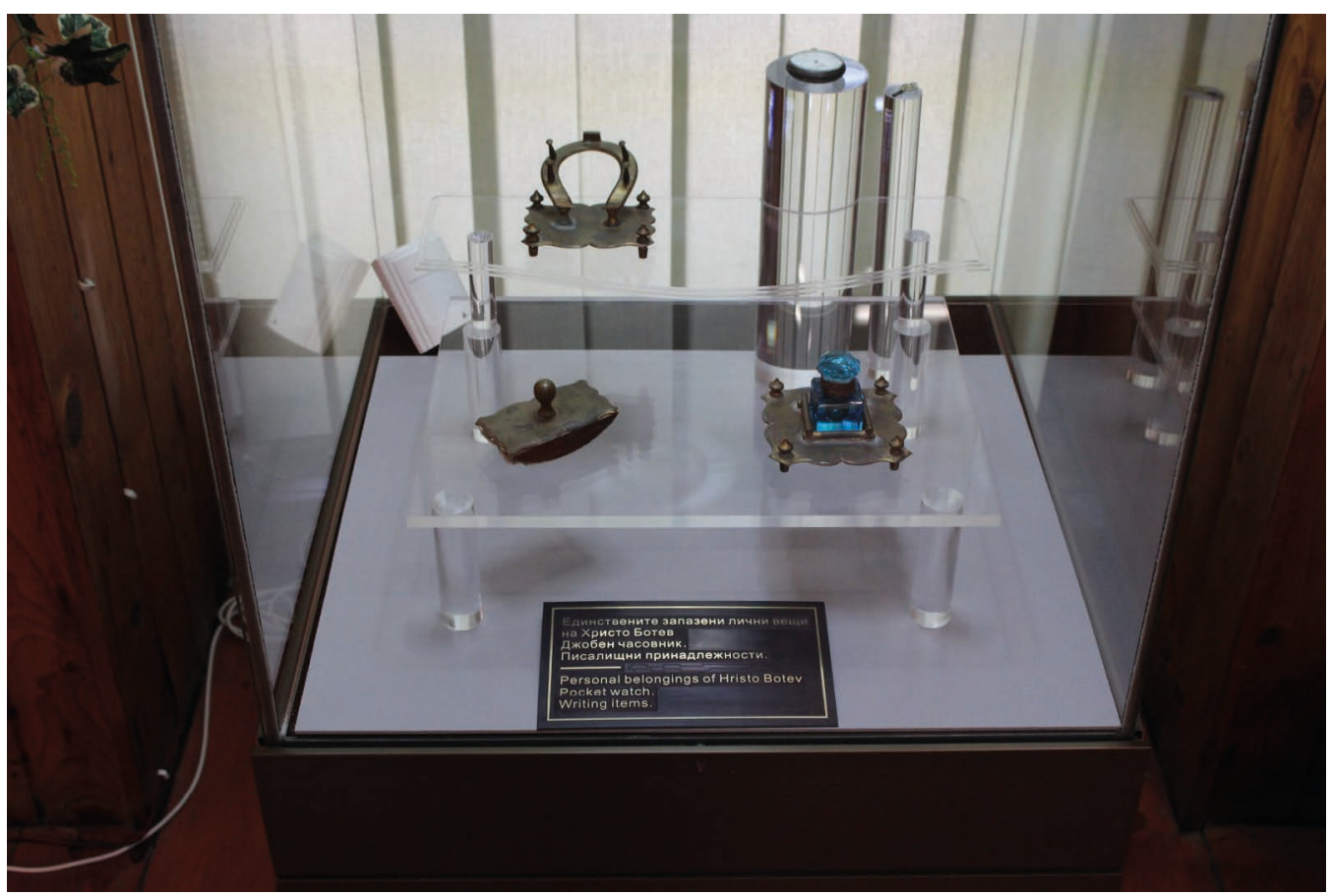

Photo 1. The personal belongings of Hristo Botev (Fot. Iskren Velikov, 2017)

The Vasil Levski Museum in the town of Lovech also presents the hero's personal belongings in a special display case. It is located on a different level from the main exhibition belt, at the base of a high decorative panel, where its image is presented in full length with outstretched arms to the attributes of the revolutionary oath (pistol and knife, crossed over the Bible). The annotation reads: „The personal weapon (sword and knife) of Vasil Levski”. Here again there is no account of the objects themselves - production, history of use, history of acquisition, and their location separates them into a kind of altar for worship 1 .

Panayot Volov's belongings in his memorial house in Shumen are displayed in a separate case at the end of the exhibition. The rifle's annotation reads: „Panayot Volov's rifle, with which he proclaimed the uprising in Panagyurishte on April20,1876 and took part in it.” This is the only one of the three examples

${ }^{1}$ The display case itself has wide base and low height, standing over a narrower leg an outlook which resembles a church altar table. 


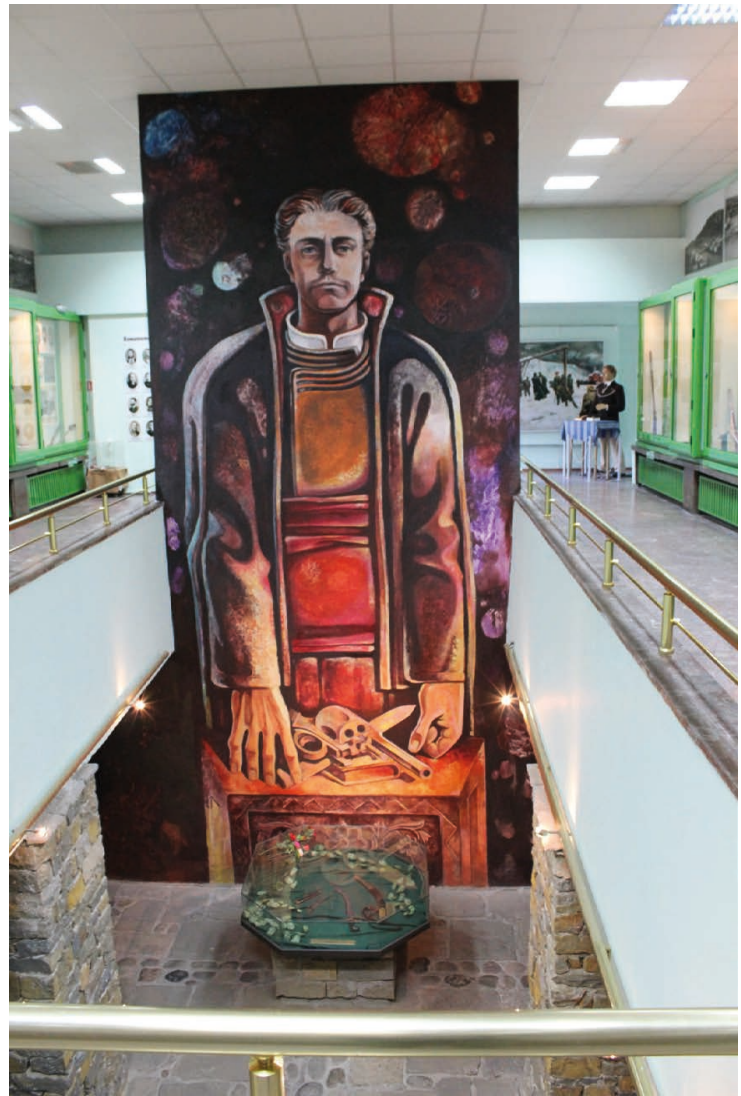

Photo 2. The personal weapon of Vasil Levski in Lovech (Fot. Iskren Velikov, 2017)

where the information about the relictells, albeit briefly, about the history ofits use. The chronological (event) contextualization is supplemented with a figurative one, as the subject is located in front of a reconstruction of an insurgent uniform from the April Uprising, which represents the vision of the voivode. The considered examples show situations in which the relics are presented independently and perform the role of a center in the construction of the exposition. The role of the original bell in the Klisura Museum of History and the replica bell in the Bulgarian Revival Museum in Plovdiv is similar. Constructed in this way, the exposition construction decontextualizes the relics, but also turns them into a place of homage to the memory of the hero or the event - a function typical for most of the museums of the Bulgarian Revival, and referred by L. Jordanova as a general method to gain knowledge from a museum [Jordanova 1989: 25].

Representations are designed to fill the lack of relics from the character or event. This is the largest category of exhibits in the context of the presenta- 
tion of the National Revival. In a general sense, they are originals, but they do not belong to the declared context.

This category of items includes mostly everyday items - utensils, tools, textiles. There are also cases of weapons that illustrate the armaments of the era. In this sense, the exhibits-representations aim to fill the lack of relics, but without resorting to replicas, so as not to lose the „charisma of the original”.

The topic of the use of ethnographic materials in the construction of exhibitions for the National Revival has been in scientific circulation since the middle of the 20th century. In her article on the subject, Raina Pesheva theorizes on the issue and identifies two main methods for its applicationthe use of ethnographic materials as a complementary and as a main means of influence [Pesheva 1957: 15]. It defines the impact of the items as „more immediate" and compensatory to the scientifically important but insufficiently visual documentary evidence. Field observations allow testing the hypotheses of the researcher in their practical application.

The Byala Cherkva Museum of History is established in 1976 and for the most part reaches our days without changes. The narrative for the National Revival occupies a large hall, divided into threesectors, the information boards are 23 in number (with photocopies of documents, texts and photographs), four decorative panels and a total of five display cases with materials from the period. The permanent exhibition can be perceived as a representative of the method in which ethnographic materials play a complementary role to the main documentary evidence. The items include men's and women's costumes, home-woven pillows, belts and aprons, goatskin, Ottoman coins. The aspiration of the people of the town to achieve freedom is presented with a rifle, exposed in front of the men's costume, gunpowder in a horn, forged swords.

On the opposite pole is the example of the Philip Totyu House Museum in the village of Voneshta Voda. There, the visitor can see a reconstruction of a room from the period, and all items on display were donated by residents of the region - three-legged chairs, wooden and ceramic utensils, coins, fabrics. However, none of them belonged to the main figure. The exhibition has no information panels, copies of documents or photographs. In this way, the museum shows the everyday life of the local community in the period of the XIX century, but through the story of the native house of Philip Totyu. The image of the voivode has been identified by the locals as one of them a representation of the community, with all the prestige stemming from this 
affiliation. The Philip Totyu House Museum in Voneshta Voda illustrates the use of ethnographic materials as the main means of building a historical exposition [Pesheva 1957: 20].

The Angel Kanchev House Museum in Tryavna shows a balanced approach between the two extremes. The exhibition is arranged in the native house of the hero, and on the second floor it is developed in four rooms. Two of them present an ,authentic interior” - living room and the birth room of Angel Kanchev. In the other rooms, display cases show items that belonged to local activists of the revolutionary movement, as well as weapons from the time of the Russian-Ottoman War (1877-1878). The exhibition on the ground floor is more of a commemorative character - a plaster cast of the hero's personal weapon is on display, monuments and plaques are on display, and his revolutionary path is outlined on a map. The House Museum shows a balanced approach in which the relics - the original items of the era associated with specific names, even if they did not belong to the main character in the story - are exhibited in a classic museum environment in windows, with annotations and supported by visual aids. Ethnographic materials were used to represent the era by constructing a reconstruction of the home environment, as we see in many memorial houses.

The replicas of artefacts, made for the needs of the exhibitions, illustrate the need for specific items for the construction of the museum narrative. In the case of the museums for the National Revival, these are most often uniforms of revolutionaries, detachment banners. A separate display case at the Hadji Dimitar House Museum in his hometown of Sliven shows a reconstruction of the flag of the detachments, created according to the descriptions of contemporaries. The flag is also in focus in the presentation of Januarius McGahan's testimonies about the atrocities of the Ottoman government during the suppression of the April Uprising in Panagyurishte. Acommon motif is the presence of a „cherry-trunk cannon” in many permanent exhibitions, which varies both in size and appearance. These items are associated entirely with the revolutionary activity of the main character and give imagery to his heroic behaviour and actions.

\section{The World of the hero}

Combined together, the relics, representations and replicas breathe life into the „world of the hero”. This world includes the Home in which he was born or grew up, i.e. the environment in which he is formed as a person and which 


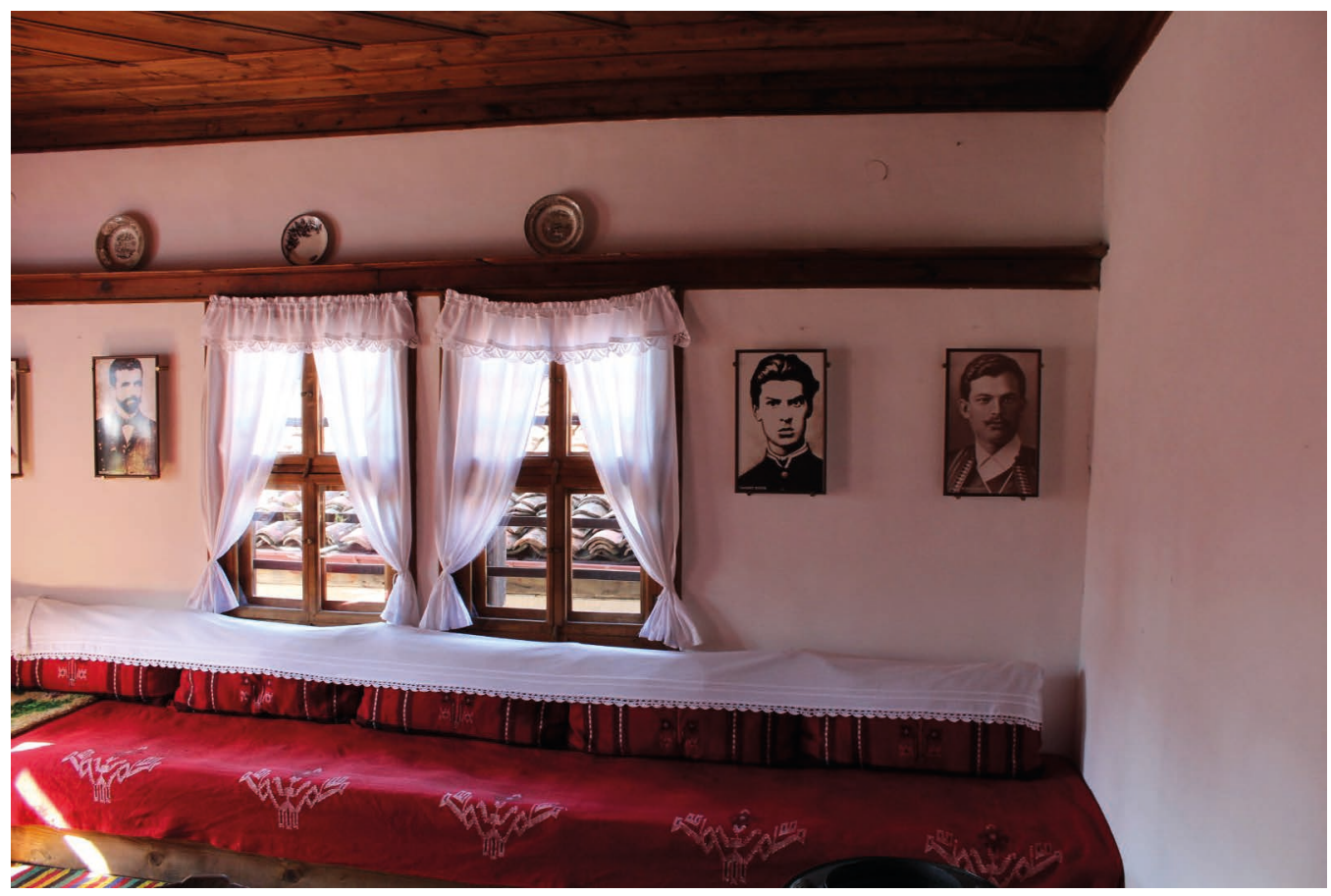

Photo 3. The use of walls as exhibition space for images at the Georgi Benkovski Museum (Fot. Iskren Velikov, 2017)

has merit for his virtues. Constructed in an extremely identical way, this setting contains „mandatory” elements that are observed in all house museums: a fireplace, a table and three-legged chairs, rugs and carpets, utensils, chests, baby swing, spinning wheel, paintings and photos on the walls. The claim to recreate an authentic environment is violated precisely by the last element, which is always at odds with the reconstructed period. For example, in the annotated room in the Georgi Benkovski House Museum in Koprivshtitsa, we see hanging portraits of the revolutionaries in the April Uprising from the region, which were especially popular during the period of socialism. In the Rayna Knyaginya House Museum, next to the place where she hid the rebel flag, we see a photograph of her from 1901 with the same flag. In this way, the walls go beyond the context of the recreated setting and perform the functions of museum showcases, without being such. Another common point in the reconstructions of an authentic environment is the presentation of tools or products related to the livelihood of the hero's family.

Beyond the boundaries of the reconstruction of a room from the time the hero lived in the house, the story of him passes within the exhibition areas. Traditionally, there the narrative develops in shop windows with objects 
and visual evidence - photographs and lithographs, excerpts from documents. The objects are located at the base of this construction and contain short scientifically formulated annotations.

\section{Artefacts on Display}

Which are the items, observed most often in the museums for the National Revival period? Does any of the group of artefacts possess a dominant role over the others? Is there an item, which appears instantly in the visitor's mind as association for the term "National Revival"? Despite the diversity of artefacts from the period, exhibited in the display cases, the presentation approach in the permanent exhibitions establishes specificimages, associated by the visitors with the Bulgarian National Revival period.

Weapons. This is the most direct association with the permanent exhibitions for the Bulgarian National Revival. Although this group of items does not have dominance in numbers over the general composition of the exhibitions, the presence of cold and firearm weapon usually occupies central (or one of the central) places in the permanent exhibitions, especially when it has belonged to a hero from the National Pantheon. The narrative for the National Revival in the town of Kazanlak is developed in two halls of the Museum of History. Various types of firearm weapons are present in every single element of the narrative - for the crafts and adornment, for the everyday life, for the movement for secular Bulgarian education and independent church, and of course in relation to the revolutionary activities and the Russian-Ottoman war of 1877-1878. One of the central compositions presents a Russian small-caliber gun, shells, as well as pyramids of rifles with bayonets. The firearms are present on walls, inside the display cases, but often without annotations. Thus, within the frames of the narrative construction, weapons are playing scenography role, using the charisma of its authenticity, but does not narrate a specific story.

Documents. The documentary heritage is present steadily in all exhibitions about the National Revival, regardless of the theme of presentation, but it does not have the charm of items. We see originals and phototype copies of documents from the epoch, for example, as a basis for the presentation of the permanent exhibition at the Kotel Museum of History. Similar copies of documents are visible in many exhibitions for the period, especially those designed and constructed under socialism. Due to the idea of mandatory accompaniment of the visit with a guided talk, some of the documents 
are present silently on the information panels - without an annotation to „translate” them (and sometimes literally) into a modern language. However, the presence of documentary evidence within the museum narrative aims to verify its veracity and guarantees canonicity.

Visual documents. They are the other „mandatory” element in any exhibition for the National Revival. Numerous lithographs, photographs, graphics from foreign newspapers and travellers provide the necessary imagery for the period. The importance of the topic of photographic works from the National Revival came to the fore once again in 2018 after a study by a museum specialist from the Vasil Levski National Museum, as a result of which a portrait of the hero was found in the state archives in Istanbul. Although the presented image is not new to the scientific community - it is known that this is the photo on which the Ottoman government was looking for Vasil Levski, the news received a wide response on national level.

Uniforms. Along with weapons, uniform is the other attribute, used by exhibitions in their effort to construct the hero's image. Due to the lack of preserved originals, in most of the cases the Bulgarian museums use copies and restorations by descriptions from the period. The Museum of the National Revival and Constituent Assembly in the town of Veliko Tarnovo displays several such reproductions of uniforms. One of them ${ }^{2}$ consists of a coat and breeches with light-coloured base and green ornaments, made in the style of the Hussars' uniforms of Central Europe in that period.

Banners. As symbols of the armed struggle for national freedom, banners and standards occupy an important place in the exhibitions' structure. Originals and reconstructions illustrate the idea of a new stage in the search for a way to political independence; battle flags are an inalienable symbol of the idea of organization and coordination in battles. The Panagyurishte Museum of History displays a banner from the April Uprising, marked with №12. The flag is one of the twelve made for the uprising detachments of the Fourth Revolutionary District [Nenov 2018: 75].

Personal items. This tensile concept is able to address various kinds of items, but is present durably in these museum permanent exhibitions. The reason for the personal items to form a separate category is due to the role of their original owner in the frame of the museum narrative. One of the lasting "is-

\footnotetext{
${ }^{2}$ The exhibited uniform is associated with the personality of Ivan Panov Semerdzhiev one of the leaders of the April Uprising in 1876, executed in the town of Veliko Tarnovo in the same year.
} 
sues", faced traditionally by the specialists on the Bulgarian National Revival period, is the fact that the museum institutions keep very small amount (and sometimes none) of items, which have belonged to the main character of the exhibition presentation. This understanding manifests a thinking in the spirit of the Classical Museology, where the "item-relic" is an obligatory foundation for the construction of the narrative. In this case the artefact is presented in an encyclopaedic style with all of its characteristics - material, origin, dating, belonging; without it, the one-direction delivery of information from the "monopolist over its contents" (the institution) to the passive recipient (the visitor) cannot be executed.

With the clear differentiation between "personal weapons" and "personal items" of the hero, the latter can be highly diverse. The "Todor Kableshkov" House Museum in the town of Koprivshtitsa, for instance, displays the textbooks, used by the main character, as well as the hat from his uniform as clerk at Baron Hirsch's Railway. There is also one page from "The Count of Monte Cristo" novel, translated by Todor Kableshkov in Bulgaria.

Artefacts from pre-Modern time. They are widespread in this type of museums - practically every restoration of the interior of a memorial house presents to the public a scene with a patriarchal sound. The second hall of the Angel Kanchev House Museum in the town of Tryavna illustrates a system of a living room - a fireplace with a fire-iron, a tripod, pots, a low table with three-legged chairs, wooden chests. The floor of the room is covered with rugs, and on the shelves on the walls are arranged pottery vessels. With different variations, these are the most common objects that represent this part of the traditional home in the permanent exhibitions of the museums for the Bulgarian National Revival, especially in the memorial house of figures from the National Pantheon.

Signs of Modernity. The artefacts, related to the Modern times - the European inventions of the 19th century - also find place in the permanent exhibitions for the Bulgarian National Revival. Apart from their vision and function, these items are usually attractive for their origin as well - the revolver swords of Hadji Dimitar and Stefan Karadzha are invaluable because of their connection with the names of the characters, but also arouse interest with the combination of cold steel sword and a firearm gun, a product of European technical thought.

Models. Reduced-scale models are present most often with the purpose to present architecture examples. For this reason, we see many of them in the 
permanentexhibition of the Kolyo Ficheto ${ }^{3}$ Museum ofHistoryinhis hometown of Dryanovo - 13 in number. They show his most famous works - bridges, churches, office buildings, bell towers, fountains. A model of a residential town from the early $19^{\text {th }}$ century in the Konaka Museum in Vidin illustrates the peculiarities of construction, related to the insecurity in the Ottoman Empire.Four scale models of the "Radetzki" steamboatin Bulgarian museums are dedicated to tell the story of the April Uprising in 1876.

Maps. The geographical localization of an event or the lifespan of a hero appears as one of the often-used subjects in exhibitions. Only within the premises, dedicated to the National Revival, the Museum of History in the town of Pazardzhik displays six maps of the area, representing mainly commercial connections and revolutionary activities. In addition, the maps are mounted over light-boxes, which are meant to produce the feeling of motion within a clearly static exhibition environment. Such attempts, created during the 1970s, are visible in other museums in Bulgaria ${ }^{4}$, all of which dedicated to the April Uprising of 1876.

The indicated groups of artefacts, which stand out within the composition structure of the permanent exhibitions, define the characteristics of the image for the Bulgarian National Revival, formed by museums. The period is outlined as a time of armed struggle for achieving national independence; a time of heroism, when the main characters are standing solidly over the foundations of traditional society, but are also open towards the new ideas of Modernity; a time of physical construction, which has left behind serious in quantity documental and visual legacy.

\section{The Kakrina Inn Museum: a traditional National Revival}

Vasil Levski (1837-1873) is a national hero, founder of the Internal Revolutionary Organization in the 1860s and the 1870s in Bulgaria. His image among the various groups of audiences is entirely undisputable and is referred as full of virtues. On December 26,1872, Vasil Levski was captured and arrested by the Ottoman forces at the village of Kakrina. In February 1873 he was sentenced by an Ottoman court and executed in Sofia.

\footnotetext{
${ }^{3}$ Nikola Fichev (Kolyo Ficheto, 1800-1881) is a widely popular builder. His works - mainly in Central North Bulgaria - are considered to be the peak of Bulgarian architecture during the National Revival.

${ }^{4}$ The examples in hand are the Panayot Volov House Museum in the town of Shumen, as well as the Dryanovo Monastery Museum.
} 
Nowadays, the building of the Kakrina Inn houses an exhibition whose story is focused entirely on the capture of Vasil Levski. It is deployed in five rooms, entirely on the principle of „interior restoration” — with places for eating and cooking, wooden beds for sleeping, storage room and mangers for domestic animals. There are no display cases with exhibits and information boards. Exceptions are three excerpts from forensic interrogations displayed on one of the walls, as well as three photographs. The Kakrina Inn presents to the visitors an image for the Bulgarian National Revival, constructed entirely on the ground of the pre-modern Bulgarian society. Various three-legged chairs with a difference in height, arranged around a low wooden table, illustrate the places for eating. The dishes are made of pottery with wooden utensils, and the food is cheese, bread and bacon. The floors are carpeted and the beds are covered with woollen fabrics. In the storage room you can see pitchers, jugs, jugs and a large tub. Firewood is arranged in the room with the manger for the animals, and tools such as the bull, the hammer, the grater are scattered on the ground. The end of the exposition story is outside the building — at the fence, built of woven sticks, where, according to historical evidence, Levski hung his shoe and could not escape.

The Kakrina Inn Museum presents a story that is correct in relation to the historical „canon” of the Revival. The constructed imagery has a distinct ethnographic character, but the story is completely subordinated to the

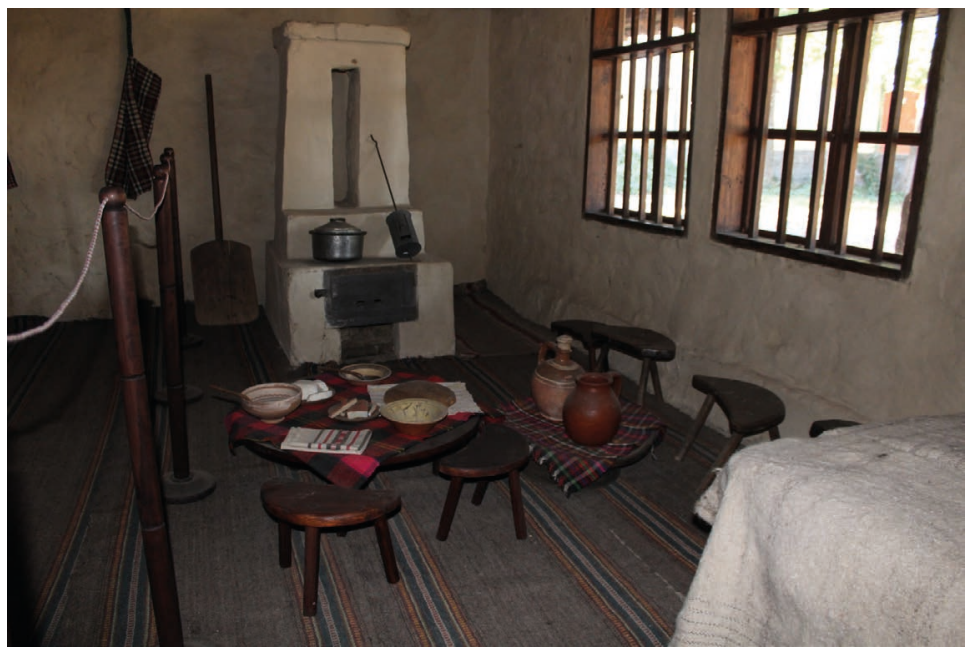

Photo 4. Interior of the Kakrina Inn (Fot. Iskren Velikov, 2017) 
idea of presenting a specific historical event — the capture of Vasil Levski on December 26, 1872.

\section{The Dobri Voynikov House Museum: a Modern National Revival}

DobriVoynikov(1833-1878) is a public figure, a teacher, founder of the Bulgarian theater, participant in the struggle of churchindependence, one of the founders of the Bulgarian Academy of Science. In 1862, in his hometown of Shumen, he built a large house, which nowadays is a museum in his memory.

Through items and interiors, the memorial house of Dobri Voynikov shows an environment that we usually do not associate with the National Revival. In five rooms on the second floor of the house, the permanent exhibition narrates about the interior of a Revival home. In this case, the „Revival home” is a homeworld, designed entirely in the spirit of Modern times-European-style furniture, chairs Thonet, silverware and crystal glasses, richly ornamented wall clocks, musical instruments (piano, clarinet), desk from Slovenian oak. The walls of the rooms are not painted, but the curtains and cornices on the windows are completely synchronous with the European fashion of the 19th century. On the wall behind the desk in Voynikov's office we see a phototype copy of a painting depicting Georgi Rakovski in haidouk clothes, with a flag and a rifle, walking over the flag of the Ottoman Empire.

The Dobri Voynikov House Museum presents a Bulgarian Revival world, constructed in the style of the New Age in Europe. Taking occasion from the activities of the main character, the permanent exhibition shows the new elements of school and cultural life, the manifestations related to the leisure time of the citizens of Shumen - a result of the European influence after the construction of the railway line Ruse-Varna. The image of the National Revival, proposed by the permanent exhibition, is one-sided - it focuses only on Modernity, differs greatly from most Bulgarian museums, and diversifies the static behaviour in exhibiting.

These examples illustrate an approach that is not visible in other Bulgarian Revival museum presentations. They, in turn, present the era as a time of transition from the traditional to the modern, creating an environment in which the exhibits coexist without conflict. For this reason, in the restoration of the interior, where the main group of objects are typical of premodern, we see a wall clock or porcelain. The artefacts construct an idea of the dynamics of social development, in which the virtues of the „old” society 


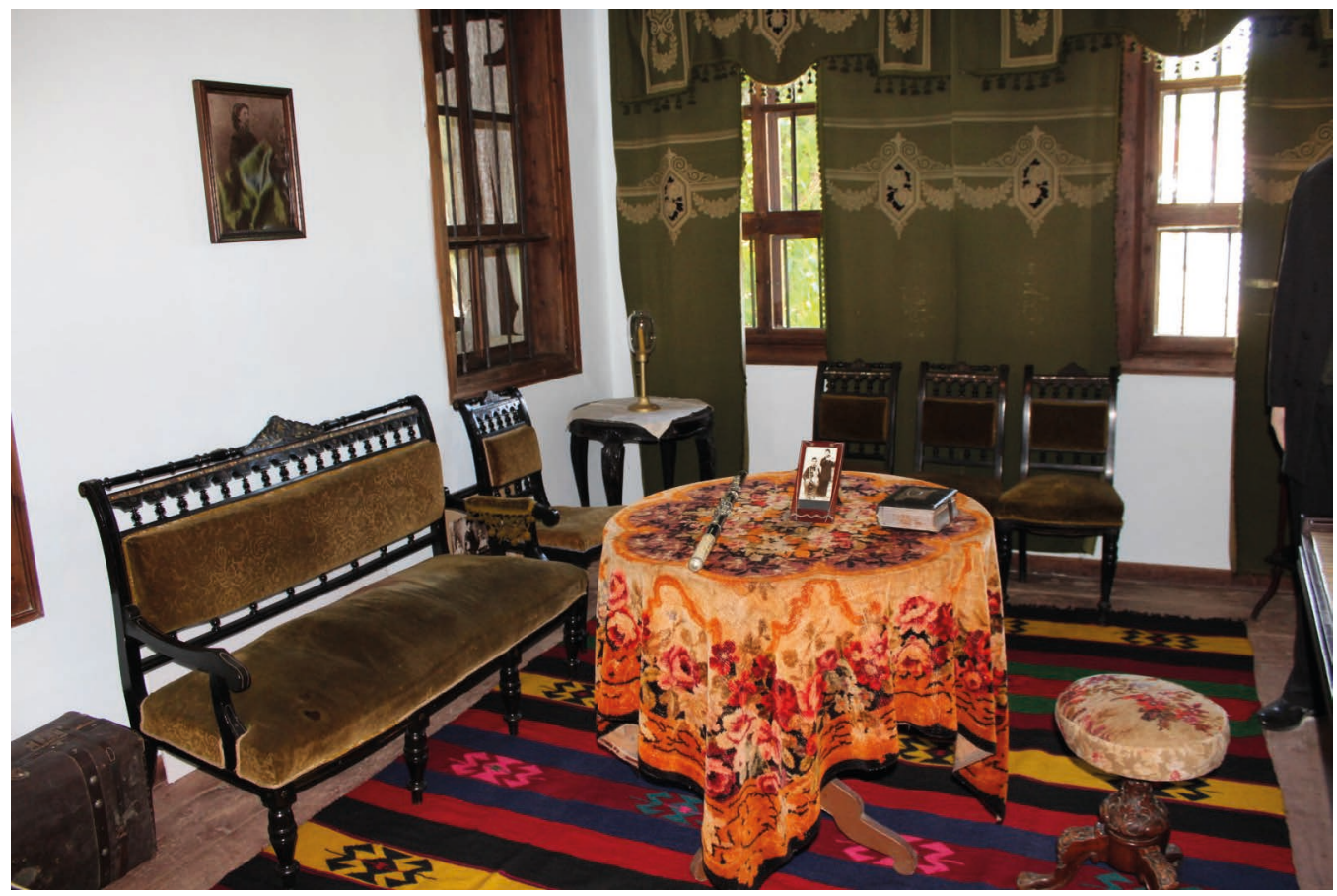

Photo 5. Interior of the Dobri Voynikov House Museum (Fot. Iskren Velikov, 2017)

are complemented by modern European ideas of the era, and innovations in the life of Bulgarians happen only for the better.

The presence of the exhibits in the museums of the Bulgarian National Revival is completely subordinated to the general presentation idea. Their main function is to illustrate the specific topic - the photograph visualizes a figure or location, the document testifies to the truth, and the personal belonging evokes adoration. From this point of view, artefacts play a supporting rather than a cataly tic role - instead of ,items with history”, museums show „history complemented by items”.

The presentation of the Bulgarian National Revival in a museum environment coincides entirely with the image of the period built by Bulgarian historiography - a time of change, of valour and self-sacrifice. According to the same logic, the leading moment in the image of the time of formation of the Bulgarian nation is the armed struggle for political freedom, and the figures who stand out with their names are precisely the people who carried out this struggle.

Museum representations of the National Revival create and affirm images of the period, the manifestations of which go beyond the institutions of memory. The reasons for the wide influence of the heritage from this 
period can be found both in its national-consolidating role and in the performative aspects of the museum narrative [Kazalarska 2018], which allow the visitor to read the story beyond the control of the museum. institution.

\section{Bibliography}

\section{Baudrillard Jean}

2003: Sistemata na predmetite. Sofia: LIK.

\section{Hooper-Greenhill Eilean}

2000: Museums and the Interpretation of Visual Culture. London and New York: Routledge.

\section{Jordanova Ludmilla}

1989: Objects of Knowledge: A Historical Perspective on Museums. In: Vergo, Peter (ed.) The New Museology. London: Reaktion Books, pp. 22-40.

\section{Kazalarska Svetla}

2018: Muzei irazkaz. In: Piron Magazine, vol. 15. Sofia [http://piron.culturecenter-su.org/ wp-content/uploads/2018/03/Svetla-Kazalarska-Museum.pdf].

\section{Nenov Nikolay}

2018: 100 artefakta ot geroichnoto vreme. Vizualni razkazi v muzeia. Sofia: IIK ROD.

\section{Pesheva Rayna}

1957: Etnografskite materiali v ekspoziciata na razdela Natsionalnoosvoboditelni borbi. In: Muzei i pametnitsi na kulturata Magazine, book 1, pp. 15-23.

\section{Roshkeva Reneta}

2018: Оръжието на революционерите в българските музеи като наследство. In: Balgarska etnologia, book 1, pp. 111-131.

\section{Walsh Kevin}

2002: The Representation of the Past. Museums and Heritage in the Post-modern World. London and New York: Routledge, 2002.

\section{Iskren Velikov}

\section{Artefacts on Display: Museum Narrative for the Bulgarian National Revival Period}

Bulgarian museums, which present the National Revival period, form a whole category of exhibitions, the specifics of which are recognizable to a wide range of audiences. The messages in these museums are not entirely unknown; on the contrary - there are certain preliminary expectations for them, the answer to which leads to satisfaction from the visit. In the minds of many Bulgarians, visiting these exhibitions, as well as the satisfaction of this act, are „mandatory”. The artefacts construct an idea of the dynamics of social development, in which the virtues of the „old” society are complemented by modern European ideas of the era, and innovations in the life of Bulgarians happen only for the better. The presence of the exhibits in the museums of the Bulgarian National Revival is completely subordinated to the general presentation idea. Their main function is to illustrate the specific topic - the photograph visualizes a figure or location, the document testifies to the 
truth, and the personal belonging evokes adoration. From this point of view, artefacts play a supporting rather than a catalytic role — instead of ,items with history”, museums show „history complemented by items”.

Keywords: Bulgarian National Revival, museums, artefacts, narrative 